\title{
AUDIÊNCIA UNA EM PROCESSO DE APURAÇÃO DE ATO INFRACIONAL:ANÁLISE DO SISTEMA PROCESSUAL PREVISTO NA LEI 8.069/90 SOB O CRIVO DE PRINCÍPIOS CONSTITUCIONAIS CONSAGRADOS TAMBÉM NA LEI N¹1.719/081
}

\author{
A trial on a case in the scope of the \\ discovery within status offenses: Analysis of \\ a procedural system under the law 8.069/90 \\ under the laws of the constitutional principles \\ therein the law 11.719/08
}

\section{Juniara Cristina Fernandes Orthmann ${ }^{2}$}

Resumo: Este artigo objetiva analisar a ilegitimidade do método processual previsto no Estatuto da Criança e do Adolescente para colheita de prova oral em processo de apuração
Abstract:This article aims to analyze the procedural illegitimacy of the method provided in the Brazilian Children and Adolescents Statuteabout collecting testimony evidences

1 O presente artigo, adaptado para este fim, é fruto de Trabalho de Conclusão de Pós-Graduação em Direito Público orientado pela Mestre Brigitte Remor de Souza May e submetido à banca examinadora da Universidade Regional de Blumenau (FURB) como requisito à obtenção do título de especialista no ano de 2013.

2 Pós-graduada em nível de especialização em Direito Público em Curso promovido pela Universidade Regional de Blumenau (FURB) em parceria com a Escola Superior da Magistratura do Estado de Santa Catarina (ESMESC). Bacharel em Direito pela Universidade Federal de Santa Catarina (UFSC). Assessora Judiciária lotada na $1^{\text {a }}$ Vara Criminal da Comarca da Capital no período de julho de 2009 a abril de 2011. Atualmente, Assessora Jurídica junto ao Gabinete da Juíza Titular da Vara da Infância e Juventude da Comarca da Capital, Dra. Brigitte Remor de Souza May. E-mail: juniara_o@hotmail.com 
de ato infracional.Por meiode um sistema dedutivo, almeja-se evidenciar a possibilidade de apresentação do adolescente e oitivas de testemunhas em audiência una, tal como convencionado atualmente à esfera criminal. Para tanto, inicialmente, evidenciou-se, frente o princípio da economia processual, a relevância de um procedimento ágil. Ainda,questionou-se se o sistema da Lei $n^{\circ} 8.069 / 90$, ao cindir atos de instrução, evita a excessiva duração da instrução probatória e cumpre, da maneira mais célere, os prazos processuais exigidos naquela Lei.Abordaram-se também os princípios da oralidade e da concentração no processamento de representação em face de adolescente, bem como foram avaliadas suas consequências. Referida avaliação conectou-se diretamenteao princípio da presunção de inocência dianteda frequente assunção de culpa pelo adolescente na apuração de ato infracional.Ao fim, concluiu-se pela ilegitimidade dodesmembramento para colheita de prova oral no processamento de apuraçãode ato infracional, revelando-se a necessidade de audiência una.

Palavras-chave: Ato infracional. Procedimento. Prova oral. Audiência una. in the infraction investigation legal process. Through a deductive system, the aim is to highlight the possibility of presentingtheteenager and hearing the witnesses in uniquehearing, as currently appliedin the criminal sphere. For this purpose, initially, it was explained,under the principle of procedural economy, the relevance of an agile legal procedure. Also questioned if the system provided by Law number 8.069/90, whichsp lits the instruction acts, avoids the excessive length of the probationary instruction and accomplish, in the most expeditious manner, the procedural deadlines providedby that same law. In a second moment, it was analyzed the principleoforalityandtheprinciple of concentration of teenager infraction legal processing, as well as its consequences. That assessment is connected directly to the principle of presumption of innocence in the face of frequent assumption of guilt by the teenager in the legal process. At the end, we concluded the illegitimacy of the audience splittingto take oral proof in the teenager infraction legal process, revealing the needing of a unique audience.

Keywords: Infraction.Procedure. Oral proof. Unique audience. 


\section{INTRODUÇÃO}

No desenvolvimento de métodos processuais que busquem apurar a veracidade de fatos e, sucessivamente, aplicar-lhes definição e consequência jurídica, diferentes procedimentos surgem ao longo do tempo.

Em tal diapasão, e sem esquecer a necessidade de observância do sistema principiológico e de realizar-se uma leitura concatenada com todo ordenamento legal, suscitar-se-á ao longo deste trabalho se o procedimento atualmente previsto no Estatuto da Criança e do Adolescente para apuração do ato infracional atribuído a adolescente encontra legitimidade na Constituição Federal e no Código de Processo Penal.

Balizando ainda mais o tema, por meio de um processo dedutivo, analisar-se-á a (i)legitimidade do atual método processual previsto no Estatuto da Criança e do Adolescente para colheita de prova oral no processamento de representação em que se imputa conduta análoga a crime ou contravenção penal a adolescente.

Assim, a questão que se buscará responder é: o desmembramento da instrução probatória previsto no Estatuto da Criança e do Adolescente para colheita de prova oral em processo de apuração de ato infracional (audiência de apresentação e de continuação) possui, sob uma ótica principiológica, legitimidade?

Para solucionar tal pergunta, inicialmente, contextualizar-se-á o leitor, de forma sucinta, acerca das fases que se perpassam para apuração de conduta análoga a crime ou contravenção penal imputada a adolescente, concentrando-se na etapa judicial, que se inicia com o recebimento da representação, segue com audiência de apresentação, oferecimento de defesa prévia, audiência de continuação e oitiva de vítimas e testemunhas, bem como apresentação de alegações finais e sentença.

Em seguida, buscar-se-á apreciar, diante do constante aperfeiçoamento de métodos processuais,a possibilidade de apresentação do adolescente em audiência una para colheita de prova oral, 
tal como restou convencionado à esfera criminal com a reforma produzida pela Lei n¹1.719/08 no Código de Processo Penal.

Assim, primeiramente com enfoque à ideia de economia processual, apontar-se-á a relevância de procedimento célere e a exigência normativa desta ordem, a qual emana tanto da legislação infraconstitucional, como da própria Constituição Federal e de regramento internacional.

Concentrar-se-á, ainda, em questionar se o sistema do Estatuto da Criança e do Adolescente, ao cindir atos de instrução (audiência de apresentação e de continuação) para apuração da prática de ato infracional, evita a excessiva duração da instrução probatória e cumpre, da maneira mais ágil, os prazos processuais também exigidos naquele Estatuto, atentando-se à realidade de que o tempo do adolescente difere ao do adulto.

No afã de implantar-se cada vez mais um procedimento rápido e justo, abordar-se-á também o emprego dos princípios da oralidade e da concentração no processamento de representação oferecida nos moldes do art. 182 do Estatuto da Criança e do Adolescente, bem como avaliar-se-á outras consequências que podem referidos preceitos acarretar, tal como a eventual colheita de prova mais segura.

Referida avaliação estará diretamente ligada ao princípio da presunção de inocência, tema este do último tópico, tendo em vista a frequente assunção de culpa pelo adolescente na apuração de conduta análoga a umcrime ou contravenção penal.

Explicitados os pontos supra referidos, buscar-se-á, finalmente,consagrar o início de um novo procedimento para apuração da prática de ato infracional, o qual estará de acordo com os moldes do garantismo jurídico.

\section{A COLHEITA DE PROVA ORAL EM PROCESSO DE APURAÇÃO DE ATO INFRACIONAL}

$\mathrm{O}$ ato infracional é compreendido, nos termos do art.103 do Estatuto da Criança e do Adolescente, como a conduta 
descrita como crime ou contravenção penal. Sua eventual prática enseja apuração, que se divide em três partes: policial, ministerial e judicial, sendo a última o enfoque deste trabalho.

Uma vez oferecida representação, inicia-se a fase judicial com o recebimento de referido documento pela autoridade judiciária, a qual também designará audiência de apresentação do adolescente, decidindo, desde logo, sobre a decretação ou manutenção da internação, hipótese em que há de se observar o prazo indicado no art. 183 do Estatuto da Criança e do Adolescente.

Em seguida, é o adolescente citado e, assim como seus genitores ou responsáveis, intimado para o ato, cientificando-se, ainda, a necessidade de comparecimento na companhia de advogado (art.184, $\S 1^{\circ}, \mathrm{ECA}$ ).

A audiência aprazada inicia-se com a averiguação da constituição de patrono pelo representado, de modo que, em caso negativo, nomear-se-á defensor, conforme se lê no art. 207, $\$ 1^{\circ}$, da Lei n ${ }^{\circ} 8.069 / 90$ e art.227, $\$ 3^{\circ}$, IV, da Constituição Federal. Ainda, "deverá o magistrado certificar-se de que o adolescente teve prévia oportunidade para ser entrevistado por advogado". (CUNHA et al., 2011, p. 445).

Sanada a defesatécnica do adolescente é que a autoridade judiciária procederá à oitiva de representado e pais ou responsáveis, podendo também solicitar opinião de profissional qualificado, conforme preceitua o art.186, caput, da Lei n8.069/90.

Para Liberati (2011, p. 189), "a audiência de apresentação é momento de defesa do adolescente e de fundamental importância para que o juiz possa aferir as características da personalidade do adolescente, sua situação familiar e social, a extensão e a gravidade do ato infracional praticado".

Segundo Costa Machado (2012, p. 295):

o magistrado procederá à oitiva do jovem, colhendo os elementos necessários para a formação de sua convicção a respeito dos fatos que são imputados ao adolescente. Serão a este indagadas questões 
a respeito do ocorrido (notando-se que o jovem tem direito ao silêncio diante do juiz de direito, conforme previsto no art. $5^{\circ}$, LXIII, da Constituição da República), de sua interação com a família e a comunidade, sobre seus hábitos, frequência escolar, trabalho etc. Na audiência também serão inquiridos os pais ou responsáveis pelo jovem. Estes também serão inquiridos sobre os fatos e as circunstâncias de vida do adolescente.

$\mathrm{Na}$ audiência em pauta, é possível, ainda, que se conceda remissão ao representado. Do contrário, dar-se-á continuidade ao feito, suspendendo-se a audiência, intimando-se o causídico do adolescente para apresentar defesa prévia e designando-se, desde logo, audiência em continuação, podendo também determinar-se a realização de diligências e estudo do caso, consoante preceitua o $\$ 2^{\circ}$ do art.186 do Estatuto da Criança e do Adolescente.

Superada tal fase, em audiência de continuação, similar à audiência de instrução e julgamento, proceder-se-á à oitiva de vítimas e testemunhas arroladas na representação e, eventualmente, na peça defensiva, bem como, a critério da autoridade judiciária, serão ouvidas outras pessoas importantes para a elucidação dos fatos ou para fornecimento de dados sobre o adolescente.

Finda a fase de colheita da prova oral, bem como cumpridas as diligências e juntado o relatório da equipe interprofissional, é "dada a palavra ao representante do Ministério Público e ao defensor, sucessivamente, pelo tempo de vinte minutos para cada um, prorrogável por mais dez, a critério da autoridade judiciária, que em seguida proferirá decisão", nos exatos termos do art.186, $\S 4^{\circ}$, do Estatuto da Criança e do Adolescente.

Em que pese prever a doutrina que as razões derradeiras podem ser substituídas "por memoriais escritos, quando a sua apresentação imediata não for possível, principalmente pela complexidade da matéria tratada" (CUNHA et al, 2011, p. 446), prevalece que a segunda audiência prevista no procedimento de 
apuração de ato infracional observa "os princípios da oralidade e da brevidade, devendo os eventuais incidentes ser resolvidos, se possível, na própria audiência”. (LIBERATI, 2011, p. 191).

No mesmo sentido, em 1995, Albergaria (1995, p. 179) escrevia que a audiência em continuação "conviria ressaltar o enfoque dos princípios constitucionais do processo, que presidem ao julgamento oral. Com efeito, a fase decisória concentra-se na audiência, em que predominam os princípios do contraditório, oralidade, imediatividade e concentração".

Contudo, considerando também as constantes reformas processuais e o consequente desenvolvimento do direito, que cada vez estabelece melhores meios de assegurar garantias constitucionais e preceitos basilares da esfera processual, é de se questionar: forma há de que os princípios supraindicados - dentre outros - sejam ainda mais efetivos na apuração da prática de ato infracional? Tal questão será abordada no tópico seguinte deste artigo.

\subsection{A economia processual: binômio de razoável duração do processo e celeridade}

Tendo sempre em mente tratar-se o adolescente de pessoa em desenvolvimento, sobressalta ser primordial a atuação célere e, consequentemente, aplicar-se o princípio da economia processual.Isso significaque "o Estado deve procurar desenvolver todosatos processuais em menor tempo possível, dando resposta imediata à ação criminosa e poupando tempo e recursos das partes". (NUCCI, 2008, p. 43).

Tal presteza foi, inclusive, consagrada pela Emenda Constitucional n. 45, de 30 de dezembro de 2004, que inseriu no art. $5^{\circ}$, LXXVIII, da Constituição Federal, a seguinte redação: "a todos, no âmbito judicial e administrativo, são assegurados a razoável duração do processo e os meios que garantam a celeridade de sua tramitação".

O dispositivo supra estabelece não apenas o princípio da celeridade, mas também o da duração razoável do processo, o 
qual, segundo Bulos (2011, p. 692), determina que "as autoridades jurisdicionais (processo judicial) e administrativas (processo administrativo) devem exercer suas atribuições com rapidez, presteza e segurança, sem tecnicismos exagerados, ou demoras injustificáveis, viabilizando, a curto prazo, a solução dos conflitos".

Pormenorizando o tema, escreve Nery Jr. (2009, p. 314, grifo nosso):

O princípio da duração razoável possui dupla função porque, de um lado, respeita ao tempo do processo em sentido estrito, vale dizer, considerando-se a duração que o processo tem desde seu início até o final com o trânsito em julgado judicial ou administrativo, e, de outro, tem a ver com a adoção de meios alternativos de solução de conflitos, de sorte a aliviar a carga de trabalho da justiça ordinária, o que, sem dúvida, viria a contribuir para abreviar a duração média do processo.

Ocorre que, em verdade, a ideia de celeridade e de razoável duração do processo estava disposta no sistema jurídico brasileiro muito antes de ser explicitada no art. $5^{\circ}$, LXXVIII, da Constituição Federal. Há quem diga que aqueles princípios, embora antes não expressos, decorriam da inafastabilidade de apreciação judicial (CARVALHO, 2009, p. 233), da cláusula do due processo oflaw(art. $5^{\circ}$, LIV) e do princípio da eficiência (art. 37, caput), de modo que "o constituinte [apenas] seguiu a tendência mundial de consagrar, explicitamente, os reclamos por uma Justiça rápida, ágil, objetiva, transparente e de qualidade". (BULOS, 2011, p. 693).

Ou seja, antes de sua constitucionalização, a celeridade processual era reconhecida em tratados e convenções internacionais, dentre os quais se destaca o art. $6^{\circ}, \mathrm{n}$. 1, da Convenção Européia para Salvaguarda dos Direitos do Homem e das Liberdades Fundamentais e o art. 18 da Declaração Americana dos Direitos do Homem. 
Por sua vez, a Convenção Americana sobre Direitos Humanos (Pacto de São José da Costa Rica), a qual foi celebrada em 22 de novembro de 1969 e entrou em vigor para o Brasil apenas em 25 de setembro de 1992, consagrou:

Art. 5, n 5. Os menores, quando puderem ser processados, devem ser separados dos adultos e conduzidos a tribunal especializado, com a maior rapidez possível, para seu tratamento.

Art. $8^{\circ}, \mathrm{n}^{\circ} 1$. Toda pessoa terá o direito de ser ouvida, com as devidas garantias e dentro de um prazo razoável, por um juiz ou Tribunal competente, independente e imparcial, estabelecido anteriormente por lei, na apuração de qualquer acusação penal formulada contra ela, ou na determinação de seus direitos e obrigações de caráter civil, trabalhista, fiscal ou de qualquer outra natureza.

Certo é, face às influências externas, que as concepções de duração razoável do processo e celeridade, independente de sua constitucionalização, já estavam expressas também no ordenamento infraconstitucional brasileiro, tal como previam, por exemplo, em 1995 os arts. $2^{\circ}$ e 62 da Lei n9.099, os quais orientavam, deste então,a tramitação do processo sempre sob o critério da economia processual e celeridade, dentre outros princípios.

Nucci(2012, p. 362), aliás, resume que a razoável duração do processo e a celeridade em sua tramitação, em verdade, configuram binômioque conceitua a economia processual.Referido doutrinador, ao comentar o art. $2^{\circ}$ da Lei n9.099/95, discorre:

Economia processual: significa que o ganho de tempo é fundamental motivo pelo qual o processo não pode ter longa duração.

Celeridade: decorrência da economia processual, significa a realização rápida dos atos processuais, o que permite encurtar a instrução e garantir a eficiência do Estado na persecução penal. (NUCCI, 2009a, p. 776). 
Para Ishida (2012, p. 40), o princípio da economia processual traz o dever de que sejam "empregados o mínimo de atos processuais possíveis com o máximo de resultado".No mesmo sentido, Antonni e Távora (2009, p. 53) escrevem que se deve "buscar a maior efetividade, com a produção da menor quantidade de atos possível".

Por tais entendimentos, consagrados em distintos doutrinadores, a implantação de audiência una - já aplicada na esfera penal - está de acordo com o princípio em estudo, de modo a legitimar o não fracionamento da fase instrutória também na apuração da prática de ato infracional, efetuando-se em apenas um ato a apresentação do representado e a oitiva de informantes e testemunhas arrolados, não necessariamente nessa ordem.

Em verdade, o estudo aprofundado, apesar das críticas à estrutura do Poder Judiciário, traz que a concretização da audiência una é grande passo à efetiva implantação da economia no âmbito processual, a qual compreende "o bom uso dos instrumentos formais, colocados à disposição das partes e do juiz, para que haja o mais adequado funcionamento e andamento dos atos processuais, culminando com um resultado eficiente e útil”. (NUCCI, 2012, p. 362).

De acordo com Antonni e Távora (2009, p. 53), o princípio da economia processual foi consagrado "como forma de imprimir a rápida solução dos conflitos, sem apego ao rigor formal, e tendo em mente que a procrastinação desarrazoada é asilo de injustiças não só à vítima, mas também ao imputado".

Nesse contexto, sobressaltam-se as palavras de Nery Jr. (2009, p. 315):

Se, numa demonstração de retórica jurídica, se podia dizer que 'no processo o tempo é algo mais do que ouro: é justiça', com muito maior razão se pode afirmar que a justiça tem de ser feita da forma mais rápida possivel, sempre observando os preceitos constitucionais que devem ser agregados ao princípio da celeridade e razoável duração do 
processo, como o devido processo legal, a isonomia, o contraditório e a ampla defesa, o juiz natural.

Ou seja, "a celeridade do processo se constitui em um direito subjetivo público do adolescente, porém não se pode prestar à prática da injustiça rápida, com atropelo de garantias e produção de ampla dilação probatória, devendo prevalecer a máxima in dúbio pro reo". (SARAIVA, 2010, p. 131).

Assim, a questão afeta ao momento em que o adolescente é apresentado em audiência una é também de extrema relevância.Tal ponto, muito embora não constitua o objeto deste artigo, não poderia deixar de ser mencionado, haja vista todo o estudo realizado em Trabalho de Conclusão de Pós-Graduação em Direito Público referido na primeira nota de rodapé deste artigo.

Contudo, a fim de galgar um passo por vez, esta obra almeja,primeiro, reconhecer que o problema da demora na prestação jurisdicional em processos de apuração de ato infracional tem causa também na excessiva duração da instrução probatória, consoante reconhece Ferrari (2011, p. 642), cuja solução pode ser facilmente implementada com a realização de coleta de prova e manifestação oral em um único ato.

A fim de evitar referido atraso, o próprio Estatuto da Criança e do Adolescente estabelece em seu art.100, parágrafo único, preceitos a orientarem a aplicação de medida, dentre eles sobressalta o da intervenção precoce, o da proporcionalidade e da atualidade.

Observe-se que o legislador reconheceu,em 2009, com a inclusão do parágrafo único e seus incisos pela Lei $\mathrm{n}^{\circ}$ 12.010/2009, no dispositivo supracitado, que "de nada adiantará haver a adoção de determinada providência tempos após o conhecimento dos fatos que possam constituir risco para o infante ou jovem, já que, não havendo a atualidade, poderá ser tarde demais para a intervenção”. (COSTA MACHADO, 2012, p. 170). 
Ferrandin (2009, p. 99) descreve situações em que mesmo antes do disposto no art.100, parágrafo único, da Lei n8.069/90 - o Estatuto da Criança e do Adolescente já exigia a brevidade processual, impondo-a por meio de prazos curtos, os quais foram estipulados à "internação provisória, designação de audiência, apresentação do apreendido à autoridade competente, reavaliação da medida socioeducativa imposta etc., bem como pelas punições às inobservâncias de tais prazos, retratadas, por exemplo, no art. 235".

Considerando a sobrecarga do Poder Judiciário no que toca à quantidade de processos em trâmite em Varas da Infância e Juventude - o que é ainda mais complexo em Comarcas em que inexiste unidade especializada -, evidente a dificuldade em dar-se cumprimento adequado a referidos prazos (em especial ao do art.183 da Lei $n^{\circ}$ 8.069/90, impassível de prorrogação), notadamente com a exigência do Estatuto da Criança e do Adolescente em cindir atos de instrução (audiência de apresentação e de continuação).

De outro lado, "o princípio da economia processual estabelece que o processo deve alcançar seu resultado com o menor gasto possível de recursos humanos, temporais e materiais, inclusive com o menor número possível de atos e com o mínimo custo pecuniário" (FEITOZA, 2008, p. 16).

Ora, tal qual o procedimento penal, o de apuração de ato infracional deve ser célere. Assim, se já se reconhece a audiência única na esfera criminal como elemento a asseverar presteza ao feito, nada justifica o afastamento de tal método nos processos relacionados a ato infracional. Ao contrário, o processamento da representação em pauta demanda ainda mais os meios de implantação da economia processual, celeridade e duração razoável do processo, uma vez que os adolescentes têm uma compreensão do tempo diferente daqueles que já atingiram a maioridade civil.

Saraiva (2010, p. 129) lembra que "o tempo da adolescência é a urgência, haja vista a notável capacidade de transfor- 
mação, em permanente metamorfose, cabendo relembrar Raul Seixas: $\mathrm{O}$ adolescente é uma metamorfose ambulante. A justiça tardia tende sempre a lhe produzir injustiça”.

De acordo com Nucci (2012, p. 423):

A celeridade do andamento processual produz ganho para as partes envolvidas, conferindo às Varas e Cortes, em geral, o aprimoramento da prestação jurisdicional, garantindo-se a eliminação da impunidade. Da instrumentalidade dos atos, funcionalmente dispostos a capacitar os operadores do Direito a colher provas e concluir instruções com eficiência, emana a duração razoável do processo.

Em tal diapasão, frise-se que muito além do sentimento de responsabilização do adolescente, da "eliminação de sua impunidade", da busca em abolir a falsa percepção de que "ao adolescente nada acontece”, é imprescindível que - para ser verdadeiramente efetiva contra um adolescente - a medida aplicada em sentença ao autor de ato infracional não seja "imposta tarde demais, já que então o adolescente não a relacionará com o feito cometido, que para ele passou há muito tempo, e esta será ineficaz”. (SARAIVA, 2010, p. 58).

Assim, se a realização de audiência una se coaduna com mencionada orientação, que estabelece preceito muito superior ao da estrita legalidade, tem-se que apenas com a leitura seca da lei - alheia à adequada interpretação e conjugação da Constituição Federal, do Estatuto da Criança e do Adolescente e do Código de Processo Penal - concluir-se-á pela divisão da instrução processual em audiência de apresentação e continuação ao invés de ato único.

Liberati (2006, p. 138) é cristalino ao escrever que "a lei [ ${ }^{\circ}$ 8.069/90] teve a clara intenção de estabelecer um procedimento rápido, que pudesse, no mais curto prazo de tempo, chegar à verdade material". Logo, o desenvolvimento de novos procedimentos que maior garantia deem aos princípios e obje- 
tivos em pauta (economia processual, celeridade, duração razoável do processo) exige imediata aplicação, notadamente aos adolescentes internados provisoriamente.

Nesse sentido, considerando o tempo abreviado com a realização de uma única audiência, notório que um método para dar efetividade aos princípios em análise é a realização de solenidade instrutória una, o que encontra amparo na lição de Moraes (2011, p. 115):

\begin{abstract}
A EC $\mathrm{n}^{\circ} 45$, porém, poucos mecanismos processuais que possibilitem maior celeridade na tramitação dos processos e redução na morosidade da Justiça brasileira. $\mathrm{O}$ sistema processual judiciário necessita de alterações infraconstitucionais, que privilegiem a solução dos conflitos, a distribuição de Justiça e maior segurança jurídica, afastando-se tecnicismos exagerados.
\end{abstract}

No mesmo sentido, lecionam Lamy e Rodrigues (2010, p. 226) que "a efetividade dessa garantia passa também pela existência de instrumentos processuais, que, além de serem acessíveis, sejam também céleres e efetivos na resolução dos conflitos de interesses que são levados ao Judiciário".

Portanto, uma vez evidenciada a indispensabilidade da economia processual, aliada à compreensão de celeridade e de duração razoável do processo, notadamente na esfera da criança e do adolescente (seja em razão dos curtos prazos impostos pela Lei $n^{\circ} 8.069 / 90$, seja pela importância e essencialidade de julgamento rápido ao adolescente na apuração da prática de ato infracional), resta clara a necessidade de implantação de meios a assegurar referidos princípios, tal como a audiência una, que é - diante de todo o ponderado - legítima no processamento da representação oferecida nos termos do art. 182 do Estatuto da Criança e do Adolescente pelo Ministério Público. 


\subsection{Os princípios da oralidade e da concentração}

Com o objetivo de dar concretude ao princípio anteriormente explorado (economia processual), os preceitos da concentração dos atos e da oralidade figuram-se essenciais, reforçando a conclusão de tópico anterior. Vejamos.

De maneira mais adstrita, "o princípio da oralidade significa [...] que os atos processuais devem ser predominantemente orais (tendo em vista a celeridade do processo)". (FEITOZA, 2008, p. 78). Contudo, Demercian e Maluly (2012, p. 10) alertam:

A palavra falada - é inegável - pode estar documentada nos autos, seja pela transcrição nos seus precisos termos - necessária para alguns atos, como, por exemplo, a coleta da prova testemunhal - seja pela transmissão da ideia naquilo que se mostrar essencial, como é a hipótese dos debates orais, cujas teses devem constar em ata.

Em igual sentido, extrai-se em Ishida (2012, p. 41) que "o princípio da oralidade implica preferência pelo procedimento oral, com a transmissão da ideia pela palavra falada e não pela escrituração. Esta será realizada apenas com relação aos atos essenciais".

Demercian e Maluly (2012, p. 10) concluem que há "predomínio da palavra falada sobre a escrita. A transmissão do pensamento se dá oralmente, não se objetando, como visto, a documentação dos atos essenciais praticados por meio de uma forma escrita ou equivalente".

Destaque-se que "a reforma processual penal de 2008 acolheu esse princípio [da oralidade], padronizando os procedimentos, exigindo a forma oral nos debates e na sentença”. (ISHIDA, 2012, p. 41).

Ocorre que, muito antes de referida mudança infraconstitucional, a Lei n9.099/95 - também por força do art.98, I, da Constituição Federal - já explicitava, dentre outros, o preceito da oralidade, fazendo-o inicialmente em seu artigo $2^{\circ}$ (atinente 
ao capítulo "das disposições gerais" daquela lei). Ainda, repete-se a referência principiológica no art.62 ao tratar, mais especificamente, das disposições gerais dos Juizados Especiais Criminais. Nucci (2009a, p. 776) ao comentar o art. $2^{\circ}$ da Lei $\mathrm{n}^{\circ} 9.099 / 95$ define a oralidade:

Significa o predomínio da palavra oral sobre a palavra escrita, o que traz, sem dúvida, celeridade e eficiência. Em decorrência da adoção do princípio da oralidade advêm os seguintes corolários: a) concentração: os atos processuais podem ser realizados em uma única audiência. [...] Ressalte-se, ainda, que a adoção da oralidade é determinação constitucional (art. 98, I, CF).

Silva e Souza (2008, p. 32) também compreendem que o princípio da oralidade, "se bem aplicado, permite a concentração dos atos processuais em uma audiência”. Logo, de acordo com Antonni e Távora (2009, p. 53), "do princípio da oralidade, decorrem os princípios da imediatividade, da concentração e da identidade física do julgador".

Feitoza (2008, p. 78) esclarece:

O princípio da oralidade foi expressamente previsto nos procedimentos dos juizados especiais criminais (art. 62 da Lei 9.099/1995). Mas, ele pode ser inferido para os demais procedimentos a partir das normas de celeridade, concentração (unicidade da audiência de instrução) e identidade física do juiz que foram introduzidas pela 'reforma processual penal'.

Da doutrina, extrai-se que "a concentração consiste em reduzir o rito em uma ou poucas audiências, visando a proximidade entre o julgamento e a ocorrência do fato. Impede-se, por consequência, a perda dos elementos de prova" (MENDONÇA, 2009, p. 275-276).

Corroborando tal concepção, Antonni e Távora (2009, p. 53) descrevem a concentração como "o desejo de que os atos da 
instrução centrem-se em uma só audiência, ou na menor quantidade de audiências, imprimindo também celeridade (art. 400, $\$ 1^{\circ}$ do CPP)".

Ou seja, "no processo oral é imprescindível a concentração dos atos de tal forma que as impressões colhidas pelo magistrado - ou juízes leigos - não se esvaiam com o tempo" (DEMERCIAN; MALULY, 2012, p. 12), razão pela qual "referida audiência deverá ser, sempre que possível, una. Busca-se garantir maior celeridade na produção da prova, assegurando-se, mais uma vez, a rápida duração do processo" (MENDONÇA, 2009, p. 283).

Colhe-se em Liberati (2006, p. 138) que "o procedimento de apuração de ato infracional [...] deve ser célere, o que, aliás, já estava determinado pela Constituição Federal quando instituiu o atendimento prioritário dos direitos de crianças e adolescentes".

Frise-se: a concepção de procedimento predominantemente oral com audiência una vai ao encontro da economia processual, também indispensável no processamento de representação pela eventual prática de ato infracional. Nessa medida, aquele procedimento concatena-se com o de apuração de conduta análoga a infração penal praticada por adolescente.

Referida assertiva dota-se ainda mais de força quando se compreende a particular condição do adolescente como pessoa em desenvolvimento e se constata na esfera processual a relevância em se evitar a perda de provas. Tais pontos serão esmiuçados a seguir, mas necessário ter sempre em mente que o tempo para o adulto é diferente daquele do adolescente, tal como a compreensão da consequência de seus atos, sendo primordial imprimir agilidade na apuração de ato infracional.

No mais, o desenvolvimento de novas práticas jurídicas notadamente quando construtivas e ao encontro de orientações principiológicas, tal como a audiência una - exige aplicação não apenas a segmentos restritos, e sim às mais distintas áreas, isso para cultivar sempre a consolidação do Estado Democrático de 
Direito, no qual inadmitem-se práticas em desapreço às garantias constitucionais.

Guilherme de Souza Nucci (2008, p. 722) traz, contudo, pequena ressalva à aplicabilidade efetiva dos princípios em foco: "a ideia - positiva, certamente em função da economia processual - da audiência única depende, sobremaneira, da estrutura do Poder Judiciário".

A verdade é que eventualmente pode ser necessário o desmembramento da audiência (por ausência de testemunha, falha de intimação), mas a mera possibilidade de que toda a instrução finde em uma única solenidade já é suficiente a exigir o reconhecimento de que tal é o método mais adequado.

Afinal, sopesando os efeitos, preferivel a chance de ter só uma audiência e usufruir dos benefícios advindos de tal prática - dentre eles a economia processual, o cumprimento dos curtos prazos estabelecidos pelo Estatuto da Criança e do Adolescente, o respeito à peculiar condição do adolescente de pessoa em desenvolvimento etc. - do que ser imperativo, em qualquer caso, a realização de pelo menos duas solenidades para colheita de prova oral, tal como é o atual modelo de audiência de apresentação e de continuação. Notório que esta segunda maneira não impede, em todo processo, certo retardamento temporal na conclusão da apuração.

Na esfera penal já se reconhecia, desde a exposição de motivos do anteprojeto do Código de Processo Penal relacionado ao Projeto de Lei $n^{\circ} 4.207 / 2001$, que "o fracionamento da instrução jamais encontrou qualquer justificativa que pudesse compensar a demora excessiva que proporciona à prestação jurisdicional".

Antonni e Távora (2009, p. 629) acrescentam:

A noção que norteia a reforma é de traçar regras que autorizem julgamento mais célere e que possibilite cumprimento aos preceitos constitucionais. Permeiam a interpretação do rito os princípios da economia processual, da celeridade, da concen- 
tração dos atos processuais em audiências e da identidade física do juiz.

Para Feitoza (2008, p. 77), “a 'reforma processual penal' adotou o princípio da oralidade", o qual "é ligado aos princípios da identidade física do juiz, princípio da concentração, princípio da imediação (ou imediatividade) e princípio da irrecorribilidade das interlocutórias".

Ishida(2012, p. 147) leciona que "o princípio da concentração também ganhou destaque com a reforma processual penal de 2008, consagrando a audiência una ou única, onde se ouvem a vítima, as testemunhas de acusação e defesa e o réu, nesta sequência (art. 400 do CPP)".

Avaliando, ainda, a reforma introduzida com a Lei n¹1.719/08, Antonni e Távora (2009, p. 638) aduzem:

Com a nova roupagem procedimental, o princípio da oralidade ganha destaque, com forte apego à palavra falada, notadamente quando se conclui que os debates orais passam a ser a regra, e os memoriais exceção. Ademais, o princípio da concentração também irriga o procedimento, já que os atos de instrução estarão concentrados numa só audiência.

Evidente, assim, que "a mudança, sobretudo na imposição da audiência una, determinando a concentração dos atos de prova, imprime ritmo mais célere ao procedimento", mas ao mesmo tempo "permite ao acusado um exame mais amplo acerca de seu comportamento no processo" (OLIVEIRA, 2009, p. 334).Frise-se: a consequência dos princípios da oralidade e da concentração vai além da economia processual, já apreciada em tópico anterior.

Com propriedade, Demercian e Maluly (2012, p. 10) apontam:

Via-se nesse sistema [oral] - e hoje não é diferente - a grande solução para a agilização dos procedimentos criminais e, até mesmo, a maneira mais viável para a apuração da verdade real - na qual 
há fulcrar-se todo o processo penal - e a forma de se prestar com maior equidade e justeza a tutela jurisdicional.

Tal conclusão é extraída também do anteprojeto do Código de Processo Penal relacionado ao Projeto de Lei n 4.207/2001, que registrou antes da reforma processual penal de 2008:

Os procedimentos previstos no vigente Código de Processo Penal muito se distanciam dos objetivos do processo moderno, especialmente no que diz respeito à celeridade, à defesa efetiva e ao sistema acusatório. [...] Para garantir a eficácia do processo e a ampla defesa [...] estão sendo propostos procedimentos penais ágeis e objetivos, cuja dinâmica será facilmente notada pela sociedade. São adotadas técnicas novas que garantem o cumprimento de seu objetivo, tais como [...] interrogatório do acusado somente após a produção da prova; procedimento oral, realizado em uma só audiência, ocasião em que serão ouvidas as testemunhas arroladas pela acusação e pela defesa, interrogado o acusado, produzidas as alegações finais das partes e prolatada a sentença. Um destaque deve ser conferido à economia de esforços e recursos que o anteprojeto proporciona, pois se atualmente o acusado comparece quatro vezes em juízo, com a modificação ora proposta comparecerá apenas uma, ocasião em que participará dos depoimentos das testemunhas arroladas pela acusação e pela defesa, será interrogado e será intimado da sentença.

A leitura supra permite concluir que o atual procedimento previsto no Estatuto da Criança e do Adolescente para a apuração de ato infracional não está em situação muito diversa daquela em que se encontrava o Código de Processo Penal antes da reforma de 2008. Várias são as similaridades, até porque o procedimento previsto nos arts. 182 e seguintes da Lei $\mathrm{n}^{\circ} 8.069 / 90$ em muito se assemelha ao rito processual penal anterior. 
A oralidade e unicidade de audiência, que tanto agregaram ao novo procedimento penal, inegavelmente têm forças para fazer o mesmo na seara juvenil, considerando que - além de empregarem maior celeridade, conforme já narrado acima -garantem a colheita de prova mais segura (porque atual) e atenuam o estigma de constantes comparecimentos em juízo.

Diante de todo o panorama exposto, uma vez mais é preferível interpretar questões processuais do Estatuto da Criança e do Adolescente em harmonia com a Constituição Federal, o Código de Processo Penal (naquilo que impede tratamento mais gravoso ao adolescente do que ao do adulto) e a compreensão do infante como pessoa em desenvolvimento ao invés de simplesmente seguir a letra fria da lei.

Somente assim, evitam-se males ilegítimos ao representado e consolida-se um processo mais justo, rápido e efetivo, que se concretiza na apuração judicial de prática de ato infracional com um procedimento majoritariamente oral aliado a realização de audiência concentrada.

\section{3 presunção de inocência: a assunção de culpa pelo adolescente versus a busca da verdade real}

A existência de um procedimento célere, acompanhado dos princípios da oralidade e da concentração, importa sobremaneira na colheita da prova. Isto é, a qualidade dos elementos probatórios pode ser tanto mais segura quanto mais atual for sua coleta.

Por conseguinte, ter-se-ia procedimento indubitavelmente mais eficaz em razão de um simples motivo: o decurso de pequeno lapso temporal contribui à colheita das mais singelas circunstâncias, evitando que elas se percam no tempo e, de outro lado, colaborando à formação de conjunto probatório mais próximo à realidade.

Frise-se, porém, que a adequada leitura de referidas circunstâncias deve partir, notadamente quando se trata da apuração 
de ato infracional e do contexto que envolve o adolescente, da premissa constitucional penal da presunção de inocência.

Tal preceito basilar, conhecido também como princípio da não culpabilidade, está esculpido na Constituição Federal de 1988 no art. $5^{\circ}$, inciso LVII, que dispõe: "ninguém será considerado culpado até o trânsito em julgado de sentença penal condenatória”.

De tal assertiva, conclui a doutrina que

reputa-se inocente a pessoa não culpada, ou seja, não considerada autor de crime. Não se trata, por óbvio, de um conceito singelo de candura ou ingenuidade. $\mathrm{O}$ estado natural do ser humano, seguindo-se fielmente o princípio da dignidade da pessoa humana, base do Estado Democrático de Direito, é a inocência. Inocente se nasce, permanecendo neste estágio por toda a vida, a menos que haja o cometimento de uma infração penal e, seguindo-se os parâmetros do devido processo legal, consiga o Estado provocar a ocorrência de uma definitiva condenação criminal (NUCCI, 2012, p. 264).

Frise-se também que "o estado de inocência é indisponível e irrenunciável, constituindo parte integrante da natureza humana, merecedor de absoluto respeito, em homenagem ao princípio constitucional regente da dignidade da pessoa humana”. (NUCCI, 2012, p. 264).

Tamanha é a importância do preceito da não culpabilidade, que a ele se relacionam não só a dignidade da pessoa humana e o Estado Democrático de Direito, mas também os princípios do devido processo legal, do contraditório, da ampla defesa, do favor libertatis, do in dubio pro reo e da nullapoenasine culpa (BULOS, 2011, p. 696).

Portanto, "para quebrar tal regra, torna-se indispensável que o Estado-acusação evidencie, com provas suficientes, ao Estado-juiz a culpa do réu" (NUCCI, 2008, p. 39).Ou seja, "há a necessidade de o Estado comprovar a culpabilidade do indi- 
víduo, que é constitucionalmente presumido inocente, sob pena de voltarmos ao total arbítrio estatal”. (MORAES, 2011, p. 126). Assim, "na esfera criminal, ainda que o réu admita o teor da acusação, o juiz determinará a produção de provas, havendo um cuidado maior para não levar ao cárcere um inocente, visto que estão em jogo sempre os direitos indisponíveis" (NUCCI, 2008, p. 51).

Almeja-se por tal meio "a reconstrução dos fatos investigados no processo, buscando a maior incidência possível com a realidade histórica, isto é, com a verdade dos fatos, tal como efetivamente ocorridos no espaço e no tempo. A tarefa [...] é das mais difíceis, quando não impossível”. (OLIVEIRA, 2009, p. 289).

Consoante Antonni e Távora (2009, p. 48),

é de se observar [...] que a verdade real, em termos absolutos, pode se revelar inatingivel. Afinal, a revitalização no seio do processo, dentro do fórum, numa sala de audiência, daquilo que ocorreu muitas vezes anos atrás, é, em verdade, a materialização formal daquilo que se imagina ter acontecido.

De fato, até pela relatividade do conceito de verdade, "jamais, no processo, pode assegurar o juiz ter alcançado a verdade objetiva, aquela que corresponde perfeitamente com o acontecido no plano real". (NUCCI, 2008, p. 49). Mas o que se deve buscar, nesse diapasão, é a verdade mais próxima da realidade.

Frise-se que, de modo algum, almeja-se, in casu, com a busca da verdade real (compreendida como a procura do fato mais próximo da realidade) legitimar eventuais desvios das autoridades públicas, muito menos justificar a ampla iniciativa probatória reservada ao juiz em nosso processo penal. Ao contrário, o objetivo com referida procura é criar meio para que o óbvio não tenha que ser sumulado: "No procedimento para aplicação de medida sócio-educativa, é nula a desistência de outras provas em face da confissão do adolescente”. (S. 342, STJ). 
A doutrina, na espera penal, há longa data pondera que

mesmo quando prestada em juízo, [a confissão] deverá ser também contextualizada junto aos demais elementos probatórios, quando houver, diante do risco, sempre presente, [...], de auto acusação falsa, para proteger o verdadeiro autor. As razões são várias, da motivação afetiva ou afetuosa, àquela movida por interesses econômicos. (OLIVEIRA, 2009, p. 361-362).

No mesmo sentido, Tourinho Filho (2012, p. 600) admite que "a experiência tem demonstrado que à confissão não se pode nem se deve atribuir absoluto valor probatório. Muitas vezes, circunstâncias várias podem levar um indivíduo a reconhecer-se culpado de uma infração que realmente não praticou".

Nucci (2009b, p. 84), de forma particularizada, escreve:

Houve época, já sepultada no tempo, em que se considerava a confissão como rainha das provas, ou seja, a mais importante delas. Uma vez que o réu confessasse, tudo estaria pacificado no contexto probatório e o processo criminal já estaria com seu fim delineado. Havia imensa satisfação para o julgador, visto criar-se em seu âmago a certeza de não cometer erro algum ao proferir o veredicto condenatório, afinal, o réu, em seu desfavor, confessou.

Tudo estaria em plena e perfeita evolução não fosse o mau vezo de certos magistrados, cujos ecos do passado ainda insistem em verberar nas suas sentenças, dando importância crucial às confissões dos réus. Poucos são os juízes dispostos a analisar com profundidade e detalhamento a admissão de culpa, confrontando-a, com acuidade e pertinência, em face das demais provas dos autos, aliás, cumprindo exatamente o preceituado pelo art. 197 do CPP. Erros judiciários advêm em grande número da aceitação, pura e simples, de confissões isoladamente consideradas, sem a busca da compatibilidade e concordância com o conjunto probatório completo do processo-crime. 
Portanto, quando houver perante o magistrado admissão de culpa, "a cautela se impõe. Abrir mão de um direito constitucional para entregar-se ao possível castigo advindo de sentença condenatória merece zelosa avaliação e não pode encontrar espaço no comodismo dos operadores do Direito". (NUCCI, 2009b, p. 84).

Tal assertiva ganha vigor ainda maior na esfera de apuração do ato infracional, pois, "não raras vezes, adolescentes assumem falsamente crimes cometidos por maiores, ora motivados por temor de represálias, ora em razão da equivocada crença de brandura do Estatuto da Criança e do Adolescente”. (CURY, 2010, p. 824).

No mesmo sentido, Saraiva (2010, p. 248) ensina que

não se pode atribuir valor absoluto à confissão, porque esta nem sempre é ditada por amor da verdade, como enuncia o Ministro Cezar Peluso, senão por motivos imagináveis, não raros patológicos, e por outros inimagináveis. É o que, com maior razão, deve observar-se quando se trate de procedimento contra adolescente tido como infrator.

Costa Machado (2012, p. 295) é claro em apontar que "a mera confissão do adolescente sobre os fatos que lhe são imputados não é, por si só, bastante para a procedência da ação".

Com propriedade, Saraiva (2010, p. 248) leciona:

A confissão, por si só, não desonera o órgão acusatório da prova dos fatos imputados, nem dispensa o magistrado de, não sendo caso de absolvição imediata por insuficiência de elementos probatórios, exofficio colher outros disponíveis, se a lei prevê audiência em continuação. É o que, no processo infracional, se tira a fortiori ao art. 197 do Código de Processo Penal: 'O valor da confissão se aferirá pelos critérios adotados para os outros elementos de prova, e para a sua apreciação o juiz deverá confrontá-la com as demais provas do 
processo, verificando se entre ela e estas existe compatibilidade ou concordância'.

Consequentemente, imprescindível redobrada cautela na análise de confissão de autoria pelos representados. Observa-se, porém, que outros elementos podem ser aprimorados para afastar os infortúnios supra indicados.

Destaca-se entre referidos meios a já anunciada realização de audiência célere, o que, repise-se, permite o enriquecimento da prova com a coleta de detalhes capazes de impingir ao julgador uma análise verdadeiramente crítica acerca dos fatos apurados, devendo ser considerados e questionados todos os pormenores colhidos.

Assim, ainda que não se atinja a verdade dos fatos, uma colheita de prova rápida, mas pormenorizada das circunstâncias dos fatos aliada a um juízo crítico permite ao menos a não imposição de medida socioeducativa àquele que não foi realmente autor de ato infracional, preferindo-se, por conseguinte, o princípio da presunção de inocência ao julgamento cego, baseado de forma quase que exclusiva na confissão.

Aludida celeridade, conforme já apontado inúmeras vezes, há de ser conquistada também por meio de procedimento oral com audiência concentrada, o que importará não apenas na possibilidade de atingir a verdade mais próxima da realidade, mas sim, uma vez mais, evitar-se-á que o julgamento da representação dê-se com base nas meras declarações do adolescente, já que no ato serão ouvidos também informantes, testemunhas e eventuais peritos arrolados, não apenas o representado e seus genitores.

Frise-se que, "pretender construir a proposta de uma ação socioeducativa na ideia da confissão se faz em uma maneira 'moderna' o reconstruir do modelo inquisitorial medieval, de natureza religiosa, onde a confissão se fazia imprescindível à remissão do pecado”. (SARAIVA, 2010, p. 248)

Nesse diapasão, não é apenas a necessidade de procedimento concatenado à economia processual, ao princípio da 
oralidade e ao da concentração dos atos que evidencia a imprescindibilidade da audiência una no procedimento de apuração de ato infracional, mas também o exige o princípio da presunção de inocência, considerado notadamente na busca da realidade dos fatos, ainda que haja confissão, a qual, há de se pensar, por vezes pode ser falsa.

\section{CONCLUSÃO}

Após a experiência vivida com a doutrina da situação irregular e as técnicas processuais decorrentes de tal sistema, consagrou-se no Brasil o Estatuto da Criança e do Adolescente, o qual insere com força a doutrina da proteção integral e explicita em seus arts. 171 e seguintes um procedimento para apuração da prática de ato infracional, que é compreendido, nos termos do art.103 do Estatuto da Criança e do Adolescente, como a conduta descrita como crime ou contravenção penal.

Ocorre que, desde 1990, referido procedimento não sofreu mudanças legislativas, tendo, de outro lado, o sistema processual penal desenvolvido, com amparo principiológico cada vez maior, novo rito para processamento e julgamento de infração imputada à parte ré.

Diante de tal panorama, questionou-se ao longo deste trabalho se o atual método processual previsto no Estatuto da Criança e do Adolescente para colheita de prova oral em processo de apuração de ato infracional possui legitimidade sob uma ótica principiológica.

Inicialmente, constatou-se-frente oprincípio da economia processual, em seu binômio razoável duração do processo e celeridade, que prevê o emprego da menor quantidade de atos processuais possíveis com o máximo de resultado e efetividade - a necessidade de implantação de audiência una, haja vista que ela, até mesmo, soluciona a demora na prestação jurisdicional e assegura o cumprimento de preceitos previstos no art. 100, parágrafo único, da Lei $n^{\circ} 8.069 / 90$, bem como se coaduna com 
os curtos prazos processuais impostos pelo próprio Estatuto da Criança e do Adolescente.

Os princípios da oralidade e concentração também reforçaram a conclusão de realização de solenidade instrutória una, uma vez que dão concretude ao preceito daeconomia processual e inserem elemento que respeita a particular condição do adolescente como pessoa em desenvolvimento, além de garantir a colheita de prova mais segura (porque atual) e atenuar o estigma de constantes comparecimentos em juízo.

Ressalvou-se, porém, quea qualidade dos elementos probatórios coligidos deve ser sempre realizada sob o viés do princípio da presunção de inocência, considerando notoriamente que, de forma infeliz, é comum o adolescente assumir a prática de conduta que não perpetrou.

Nesta seara, imprescindível procedimento célere, que, na análise desta obra, materializou-se em audiência una também com o fito de garantir a colheita das mais singelas circunstâncias. Assim, evita-se, também, que o óbvio tenha de ser sumulado (S. 342, STJ), já que no ato aprazado, além de serem ouvidos o representado e seus genitores, também serão inquiridos os informantes, as testemunhas e eventuais peritos arrolados, não necessariamente nessa ordem.

Por conseguinte, ponderandoos princípios constitucionais e o aperfeiçoamento de métodos processuais que consagram referidos preceitos, notadamente com a implantação da Lei $n^{\circ} 11.719 / 08$ na esfera criminal, perfilhou-se ser ilegítimo o desmembramento da instrução probatória previsto no Estatuto da Criança e do Adolescente para colheita de prova oral em processo de apuração de ato infracional (audiência de apresentação e de continuação).Ou seja, um novo procedimento para apuração da prática de ato infracional deve ser implantado, o que se inicia com a realização de audiência una, a qual efetiva, de uma vez por todas, os princípios da celeridade, economia processual, oralidade, concentração e presunção de inocência. 


\section{REFERÊNCIAS}

ALBERGARIA, Jason. Direito do Menor. Rio de Janeiro: Aide, 1995.

ANTONNI, Rosmar; TÁVORA, Nestor. Curso de Direito Processual Penal. 3. ed. Salvador: Editora Jus Podivm, 2009.

BULOS, Uadi Lammêgo. Curso de Direito Constitucional. 6. ed. São Paulo: Saraiva, 2011.

CARVAlHO, Luis Gustavo Grandinetti Castanho de. Processo penal e Constituição: princípios constitucionais do processo penal. 5. ed. Rio de Janeiro: Lumen Juris, 2009.

COSTA MACHADO, Antônio Cláudio da (Org.). Estatuto da Criança e do Adolescente Interpretado: artigo por artigo, parágrafo por parágrafo. Barueri: Manole, 2012.

CUNHA, Rogério Sanches; LÉPORE, Paulo Eduardo; ROSSATO, Luciano Alves. Estatuto da Criança e do Adolescente Comentado. 2. ed. São Paulo: Editora Revista dos Tribunais, 2011.

CURY, Munir (Coord.). Estatuto da Criança e do Adolescente Comentado: comentários jurídicos e sociais. 11. ed. São Paulo: Malheiros Editores, 2010.

DEMERCIAN, Pedro Henrique; MALULY, Jorge Assaf. Curso de processo penal. 8. ed. Rio de Janeiro: Forense, 2012.

FEITOZA, Denilson. Reformaprocessual penal: Leis 11.689/2008, 11.690/2008 e 11.719/08: uma abordagem sistêmica. Niterói: Impetus, 2008 .

FERRANDIN, Mauro. Ato Penal Juvenil: aplicabilidade dos princípios e garantias do ato penal. Curitiba: Juruá Editor, 2009.

FERRARI, Regina Maria Macedo Nery. Direito Constitucional. São Paulo: Editora Revista dos Tribunais, 2011.

ISHIDA, VálterKenji. Processo Penal: incluindo a Lei n 12.483 , de 8 de setembro de 2011. 3. ed. São Paulo: Atlas, 2012.

LAMY, Eduardo de Avelar; RODRIGUES, Horácio Wanderlei. Curso de Processo Civil: Teoria Geral do Processo, v. 1. Florianópolis: Conceito Editorial, 2010. 
LIBERATI, Wilson Donizeti. Direito da Criança e do Adolescente. 5. ed. São Paulo: Rideel, 2011.

. Processo Penal Juvenil: a garantia da legalidade na execução de medida socioeducativa. São Paulo: Malheiros Editores, 2006.

MENDONÇA, Andrey Borges de. NovaReforma do Código de Processo Penal: comentada artigo por artigo. 2. ed. Rio de Janeiro: Forense; São Paulo: Método, 2009.

MORAES, Alexandre de. Direito Constitucional. 27. ed. São Paulo: Atlas, 2011.

NERY JR, Nelson. Princípios do processo na Constituição Federal: processo civil, penal e administrativo. 9. ed. São Paulo: Editora Revista dos Tribunais, 2009.

NUCCI, Guilherme de Souza. Código de Processo Penal Comentado. 8. ed. São Paulo: Editora Revista dos Tribunais, 2008.

. Leis Penais e processuais penais comentadas. 4. ed. São Paulo: Editora Revista dos Tribunais, 2009a.

. Princípios Constitucionais Penais e Processuais Penais. 2. ed. São Paulo: Editora Revista dos Tribunais, 2012.

. Provas no Processo Penal. São Paulo: Editora Revista dos Tribunais, 2009b.

OLIVEIRA, Eugênio Pacelli de. Curso de Processo Penal. 11. ed. Rio de Janeiro: Editora Lumen Juris, 2009.

SARAIVA, João Batista Costa. Compêndio de direito penal juvenil: adolescente e ato infracional. 4. ed. Porto Alegre: Livraria do Advogado Editora, 2010.

SILVA, Willian; SOUZA, Sérgio Ricardo de. Manual de processo penal constitucional: pós-reforma de 2008.Rio de Janeiro: Forense, 2008.

TOURINHO FILHO, Fernando da Costa. Manual de Processo Penal. 15. ed. São Paulo: Saraiva, 2012.

Artigo recebido em 25/06/2015

Artigo aprovado em 27/08/2015 